\title{
PERAN HEMODIALISIS TERHADAP KADAR KREATININ DARAH PASIEN GAGAL GINJAL KRONIK
}

\author{
I Gede Purnawinadi \\ Fakultas Keperawatan Universitas Klabat, Airmadidi, Minahasa Utara, 95371, Indonesia \\ Email: purnawianadi87@unklab.ac.id
}

\begin{abstract}
Abstrak
Hemodialisis merupakan terapi pengganti fungsi ginjal berteknologi tinggi dalam upaya mengeluarkan sisa-sisa metabolisme atau racun tertentu dari peredaran darah dengan tujuan utama menghilangkan gejala dengan mengendalikan kadar ureum dan kreatinin dalam darah, kelebihan cairan dan ketidakseimbangan elektrolit yang terjadi pada pasien dengan kondisi gagal ginjal kronik. Penelitian ini bertujuan menganalisis perbandingan kadar kreatinin serum pre dan post hemodialisis pada pasien gagal ginjal kronik di unit hemodialisa RSUP. Prof. DR. R. D. Kandou Manado. Metode penelitian yang dilakukan adalah kuantitatif komparatif dengan pendekatan cross sectional. Pengambilan sampel menggunakan teknik purposive sampling. Data yang terkumpul akan diolah dan dianalisis menggunakan komputer program microsoft excel dan program Statistical Product and Service Solutions (SPSS). Data dianalisis secara univariat mencari nilai rata-rata dan analisis bivariat dengan paired sample t-test. Hasil penelitian membuktikan hemodialisis mempunyai pengaruh yang signifikan dalam upaya menurunkan kadar kreatinin darah yang berlebihan pada pasien dengan gagal ginjal kronik dengan nilai sig. 0,000 ( $<<0,05)$. Untuk penelitian selanjutnya terkait peran hemodialisis diharapkan dapat menganalisis variabel lainnya seperti kadar ureum dan lain-lain sebagai indikator fungsi ginjal.
\end{abstract}

Kata kunci: gagal ginjal kronik, hemodialisis, kreatinin.

\section{Abstract}

Hemodialysis is a substitute therapy for high-tech kidney function in an effort to remove metabolic remnants or certain poisons from the bloodstream with the main goal of relieving symptoms by controlling ureum and creatinine levels in the blood, fluid overload and electrolyte imbalance that occurs in patients with chronic kidney failure. This study aims to analyze of serum creatinine levels pre and post hemodialysis in patients with chronic renal failure in the hemodialysis unit of the General Hospital. Prof. $D R$. R. D. Kandou Manado. The research method used is comparative quantitative with cross sectional approach. Sampling using a purposive sampling technique. The collected data is processed and analyzed using Microsoft Excel computer programs and Statistical Product and Service Solutions (SPSS) programs. Data were analyzed univariately by looking for mean and bivariate analysis with paired sample t-tests. The results showed that hemodialysis had a significant effect in reducing excessive blood creatinine levels in patients with chronic renal failure with significant value $0.000(p<0.005)$. For further research related to the role of hemodialysis, it is hoped that other variables can be analyzed such as urea levels and others as indicators of kidney function.

Keywords: chronic renal failure, creatinine, hemodialysis 


\section{Pendahuluan}

Penyakit Tidak Menular (PTM) merupakan masalah sebagai penyebab kematian tertinggi yang harus dihadapi dalam upaya pembangunan kesehatan. Indonesia mengalami kenaikan prevalensi PTM terdiri dari penyakit kanker, stroke, penyakit ginjal kronis, diabetes melitus, dan hipertensi yang berdampak buruk terhadap pertumbuhan ekonomi dan produktivitas negara sebab dalam penanganannya membutuhkan biaya besar disertai jangka waktu yang cukup lama (Ridlo, 2019). Gagal ginjal kronik merupakan salah satu PTM yang memerlukan perhatian karena telah menjadi masalah kesehatan masyarakat dengan angka kejadiannya yang cukup tinggi serta berdampak secara signifikan terhadap morbiditas, mortalitas, dan sosial ekonomi masyarakat karena biaya perawatan yang cukup tinggi (Roma, 2017).

Gagal ginjal merupakan salah satu penyakit kronik yang semakin banyak terjadi di dunia. Angka kejadian gagal ginjal kronik di Amerika Serikat tahun 2012 mencapai 363 persatujuta orang pertahun dan meningkat pada tahun 2013 menjadi 117.162 kasus (Usrds, 2017). Kondisi gagal ginjal ditunjukkan dengan kehilangan kemampuan untuk menyaring dan membersihkan darah sehingga diperlukan tindakan penanganan terhadap kondisi tersebut. Gagal ginjal kronik (GGK) merupakan sindrom klinis karena penurunan fungsi ginjal secara menetap akibat adanya kerusakan nefron (Assidiq, 2018). Proses penurunan fungsi ginjal berjalan secara kronis dan progresif.

Indonesia merupakan salah satu negara dengan kasus gagal ginjal yang terus meningkat. Angka kejadian gagal ginjal kronik di Indonesia pada tahun 2013 mencapai 0,2\% (Ministry of Health Republic of Indonesia, 2017). Laporan
Indonesian Renal Registry (IRR) menunjukkan $82,4 \%$ pasien GGK di Indonesia menjalani hemodialisis pada tahun 2014 dan jumlah pasien hemodialisis mengalami peningkatan dari tahun sebelumnya. Pada 2015 pasien baru dengan penyakit ginjal kronik mencapai 21.050 orang, jumlah tersebut naik di tahun 2016 sebesar 25.446 orang. Sehingga, pasien dengan GGK di Indonesia diperkirakan lebih 150 ribu orang.

Data Riskesdas tahun 2013 secara nasional menunjukkan prevalensi penyakit ginjal kronis berdasarkan diagnosis dokter mengalami peningkatan sampai 2018 yaitu $0,2 \%$ menjadi $0,38 \%$. Provinsi Sulawesi Utara, Aceh, dan Gorontalo menempati posisi kedua $(0,4 \%)$ setelah Sulawesi Tengah (0,5\%), sedangkan tahun 2018 Sulawesi Utara menempati posisi ketiga $(0,53 \%)$ setelah Kalimantan Utara $(0,64 \%)$, dan Maluku Utara (0,56\%). Meskipun peringkat prevalensi di Sulawesi Utara menurun namun meningkat berdasarkan angka. Lebih lanjut data menunjukkan karakteristik tidak atau belum pernah sekolah merupakan variabel dominan prevalensi gagal ginjal kronis dengan proporsi pernah atau sedang cuci darah $19,3 \%$, posisi tertinggi di DKI $(38,7 \%)$ dan Sulawesi Utara pada posisi ke-22 dengan angka $13,68 \%$, dengan kata lain masih rendahnya kesadaran para penderita gagal ginjal kronis menjalani cuci darah (Kemenkes RI, 2018).

Salah satu cara menegakkan diagnosis gagal ginjal dengan menilai kadar ureum dan kreatinin serum, karena kedua senyawa ini hanya dapat diekskresikan oleh ginjal. Tes ureum kreatinin selalu digunakan untuk melihat fungsi ginjal kepada pasien yang diduga mengalami gangguan pada organ ginjal (Theresia, 2011). Kreatinin adalah hasil perombakan keratin, semacam 
senyawa berisi nitrogen yang terutama ada dalam otot. Ureum merupakan produk akhir dari metabolisme protein di dalam tubuh yang diproduksi oleh hati dan dikeluarkan melalui urin. Pada gangguan ekskresi ginjal, pengeluaran ureum ke dalam urin terhambat sehingga kadar ureum meningkat dalam darah (Indrasari, 2015).

Penyakit ginjal kronik dapat berkembang menjadi kondisi gagal ginjal tahap akhir jika tidak tertangani dengan baik, bahkan menyebabkan berbagai komplikasi dan kematian. Oleh karena itu dibutuhkan suatu terobosan baru guna untuk mencegah dan mengobatinya (Lydia, 2019). Pemeriksaan kadar ureum dan kreatinin sebelum dan sesudah hemodialisis sebagai indikator kapan harus dilakukan hemodialisis serta dapat pula menjadi indikator keberhasilan hemodialisis itu sendiri (Abdurrahman, 2018).

Upaya untuk menurunkan kadar kreatinin serum tentu saja dengan memperbaiki fungsi ginjal, perlu dilakukan cuci darah (hemodialisis) untuk mengganti fungsi utama ginjal yaitu membersihkan darah dari sisa-sisa hasil metabolisme tubuh yang berada di dalam darah. Sesuai dengan kebijakan pemerintah yang mengatur tentang pelayanan dialisis di rumah sakit yaitu pasal 22 dan 23 Peraturan Menteri Kesehatan Republik Indonesia Nomor 138/MENKES/PB/II/2009 tahun 2009 yang isinya pelayanan hemodialisis merupakan pelayanan proses pencucian darah dengan menggunakan mesin cuci darah dan sarana hemodialisis lainnya. Selain itu, dalam Peraturan Mentereri Kesehatan Republik Indonesia (PERMENKES RI) No. 812/MENKES/PER/VII/2010 pasal 1 ayat 3 menjelaskan hemodialisis sebagai terapi pengganti ginjal dengan tujuan mengeluarkan toksik uremik dan mengatur cairan, elektrolit tubuh.
Hemodialisa adalah suatu teknologi tinggi sebagai terapi pengganti fungsi ginjal untuk mengeluarkan sisa-sisa metabolisme atau racun tertentu dari peredaran darah menusia seperti air, natrium, kalium, hydrogen, urea, kreatinin, asam urat, dan zat-zat lain melalui membran semi permeabel sebagai pemisah darah dan cairan dialisat pada ginjal buatan dimana terjadi proses difusi, osmosis dan ultra filtrasi (Rendy, 2012). Tujuan utama hemodialisis menghilangkan gejala yaitu mengendalikan uremia dan kreatinin, kelebihan cairan dan ketidakseimbangan elektrolit yang terjadi pada pasien penyakit ginjal kronik (Rahman, Kaunang, \& Elim, 2016).

Penyakit ginjal kronis semakin banyak menarik perhatian dan makin banyak dipelajari karena walaupun sudah mencapai gagal ginjal tahap akhir akan tetapi penderita masih dapat hidup panjang dengan kualitas hidup yang cukup baik di samping prevalensinya yang terus meningkat sepanjang tahun, di Sulawesi Utara sendiri penyakit ginjal kronis masuk dalam salah satu penyakit beresiko, menurut data RSUP Prof. DR. R. D. Kandou Manado, penderita penyakit ginjal kronik yang menjalani terapi hemodialisis, dimana setiap pasien memiliki jadwal pemeriksaan yang telah di tentukan untuk terapi (Tandi, Mongan, Manoppo, 2014).

Berdasarkan latar belakang fakta yang telah dibahas, peneliti termotivasi melakukan penelitian yang bertujuan untuk menambah pemahaman tentang peran dan manfaat hemodialisis melalui analisis perbandingan kadar kreatinin serum pada pasien gagal ginjal kronik pre dan post hemodialisa di RSUP Prof. DR. R. D. Kandou Manado Provinsi Sulawesi Utara. 


\section{Metode}

Jenis penelitian yang dilakukan adalah kuantitatif komparatif dengan pendekatan cross sectional. Pengambilan sampel menggunakan teknik purposive sampling pada hasil pemeriksaan laboratorium kadar kreatinin darah sebelum dan sesudah tindakan hemodialisis pada pasien gagal ginjal kronik yang memenuhi kriteria penelitian yaitu yang sedang dirawat di IRINA C RSUP. Prof. DR. R. D. Kandou Manado dan menjalani tindakan hemodialisis tanpa memperhatikan jenis mesin hemodialisis yang digunaan dan durasi waktu pelaksanaan hemodialisis, serta data hasil pemeriksaan laboratorium yang lengkap. Peneliti mendapatkan rekomendasi dari pihak institusi dengan mengajukan permohonan izin kepada institusi tempat penelitian dalam hal ini kepada Rumah Sakit. Setelah ada izin atau persetujuan dari pihak rumah sakit barulah penelitian dilaksanakan.

Peneliti menggunakan data sekunder yang dikumpulkan dari catatan status pasien. Informasi yang peneliti gunakan adalah hasil pemeriksaan laboratorium yaitu kadar kreatinin darah pada subyek sebelum dan sesudah menjalani hemodialisis. Data yang terkumpul diolah dan dianalisis dengan menggunakan program microsoft excel dan program Statistical Product and Service Solutions (SPSS) pada komputer. Data dianalisis secara univariat melalui analisis rata-rata dan analisis bivariat dengan paired sample t-test.

Penelitian ini menerapkan prinsip etika autonomy, dimana pemilik sumber data mempunyai hak untuk bersedia ataupun tidak bersedia memberikan data yang dibutuhkan dalam penelitian ini. Penelitian ini tentunya bertujuan baik melalui pembuktian ilmiah pengaruh hemodialisis dalam upaya pengendalian kadar kreatinin, sehingga prinsip beneficience nyata dalam penelitian ini. Dalam pelaksanaan penelitian ini sedapat mungkin dihindari hal-hal yang berbahaya dan merugikan, sehingga prinsip non-maleficience dapat diterapkan, begitu pula confidentiality sangat dijunjung sebagai suatu kerahasiaan dan melindungi data informasi responden hanya untuk kepentingan penelitian.

\section{Hasil dan Pembahasan}

Hasil penelitian ini menggambarkan nilai rata-rata kadar kreatinin darah sebelum maupun setelah hemodialisis serta pengaruhnya terhadap penurunan kadar kreatinin dalam darah.

Tabel 1. Rata-rata Kadar Kreatinin Darah

\begin{tabular}{lccccc}
\hline & Mean & $N$ & SD & Min & Max \\
\hline pre_HD & 6.52 & 37 & 3.43 & 2,00 & 13,10 \\
post_HD & 3.60 & 37 & 2.09 & 1,40 & 7,30 \\
\hline
\end{tabular}

Tabel 1. menampilkan data bahwa sebelum hemodialisis nilai kadar kreatinin darah dari 37 pasien gagal ginjal kronik rata-rata 6,5 $\mathrm{mg} / \mathrm{dL}$ (SD 3,4 mg/dL), sedangkan setelah dilakukan tindakan hemodialisis, nilai ratarata kadar kreatinin darah menjadi 3,6 $\mathrm{mg} / \mathrm{dL}$ (SD 2,09 mg/dL). Kondisi pasien dengan gagal ginjal kronis tentunya tidak lepas dari evaluasi kadar kreatinin darah sebagai salah satau indikator fungsi ginjal. Tingginya kadar kreatinin darah sebagai bukti menurunnya fungsi ginjal. Menurut Nursiyah (2020) upaya menurunkan kadar kreatinin darah pada pasien dengan gagal ginjal kronik dapat dilakukan dengan tindakan hemodialisis, dalam penelitian yang dilakukan didapati hasil nilai rata-rata kreatinin sebelum hemodialisa adalah $12,9839 \mathrm{mg} / \mathrm{dl}$ sedangkan setelah hemodialisa rata-rata kreatinin darah adalah 4,7411 mg/dl. Tindakan hemodialisis 
digunakan dengan tujuan untuk menunda perkembangan tahapan gagal ginjal ke tahap yang lebih buruk (Dai, Peng, Xie, \& Ning, 2019).

Tabel 2. Uji Beda Sampel Berpasangan

\begin{tabular}{lccc}
\hline & $N$ & $\begin{array}{c}\text { Mean } \\
\text { Difference }\end{array}$ & Sig. \\
\hline $\begin{array}{l}\text { pre_HD \& } \\
\text { post_HD }\end{array}$ & 37 & 2.916 & .000 \\
\hline
\end{tabular}

Data yang ditampilkan pada tabel 2 . menunjukkan bahwa terjadi penurunan kadar kreatinin darah pada penderita gagal ginjal kronik yang menjalani hemodialisis dengan nilai rata-rata $2,9 \mathrm{mg} / \mathrm{dL}$. Analisis komparasi juga membuktikan bahwa hemodialisis menyebabkan perubahan nilai kadar kreatinin darah sebelum dan sesudah hemodialisis, dengan kata lain hemodialisis mempunyai pengaruh yang signifikan dalam upaya menurunkan kadar kreatinin darah, yang mana ditunjukkan dengan berbedaan nilai kadar kreatinin darah sebelum dan sesudah hemodialisis $(\mathrm{p}=0,000)$.

Hemodialisis sebagai terapi pengganti fungsi ginjal yang paling sering digunakan untuk menurunkan kadar kreatinin dan toksik lainnya di dalam darah. Cuci darah melalui hemodialisis berperan dalam mengganti fungsi utama ginjal untuk membersihkan darah dari sisa-sisa hasil metabolisme tubuh yang berada di dalam darah. Penelitian lain yang sejalan dengan hasil penelitian ini dilakukan oleh Nursiyah (2020), berdasarkan hasil uji statistik menggunakan uji Paired Sample T-Test didapatkan $p$ value $=0,000<0,05$, yang artinya ada pengaruh hemodialisa terhadap penurunan kreatinin darah pada pasien gagal ginjal kronik di Ruang Hemodialisa RSUD Dr. Chasbullah Abdulmadjid Kota Bekasi.

Hemodialisis bertujuan untuk mengeluarkan zat-zat toksik dari dalam darah. Mesin cuci darah memiliki prinsip kerja mirip ginjal manusia, yakni memompa darah demi membuang air atau sisa metabolisme keluar dari tubuh. Pada proses hemodialisis, filter pada mesin cuci darah akan membersihkan sisa metabolisme di dalam darah. Darah yang sudah bersih kemudian mengalir kembali ke dalam tubuh sehingga kadar zat berbahaya yang dapat meracuni tubuh akan berkurang (Harismi dan Lestari, 2020). Selain tujuan utama hemodialisis, perlu diperhatikan peran petugas dalam memberikan layanan sesuai prosedur melalui intervensi keperawatan yang sangat penting bagi penyedia layanan dialisis demi adekuasi proses hemodialisis dan memaksimalkan pelayanan dan mencegah komplikasi proses hemodialisis (Sitoresmi dkk, 2020). Langkah-langkah dalam menghasilkan hemodialisis yang adekuatpun harus dilakukan dengan cermat sebagai tujuan utama terapi hemodialisis pada pasein gagal ginjal (Widiana, 2013).

\section{Kesimpulan dan Rekomendasi}

Hemodialisis mempunyai pengaruh yang signifikan dalam upaya menurunkan kadar kreatinin darah yang berlebihan pada pasien dengan gagal ginjal kronik. Hasil penelitian ini diharapkan menjadi tambahan bahkan penguatan informasi mengenai manfaat hemodialisis dalam upaya meyakinkan para penderita gagal ginjal yang masih ragu dan tidak mau menjalani tindakan hemodialisis. Bagi petugas kesehatan terkait dalam layanan pada penderita gagal ginjal diharapkan dapat memberikan edukasi berbasis bukti ilmiah kepada pasien dalam upaya meyakinkan pasien tentang manfaat dalam menjalani hemodialisis. Untuk penelitian selanjutnya terkait peran hemodialisis diharapkan dapat menganalisis variabel lainnya seperti kadar ureum dan lain-lain sebagai indikator fungsi ginjal. 


\section{Referensi}

Abdurrahman, S. (2018). Perbandingan Kadar Ureum dan Kreatinin pada Pasien Gagal Ginjal Pre dan Post Hemodialisa di RSUD Bahteramas Provinsi Sulawesi Tenggara. Jurnal MediLab Mandala Waluya Vol 2 No 1 (2018) Online: http://jurnal.analiskesehatanmandalawaluya.ac.id/index.php/JMP /article/view/11/9

Assidiq, Y. (2018). Jumlah Pasien Penyakit Ginjal Kronis Terus Meningkat. Online:

https://www.republika.co.id/berita/ga ya-hidup/infosehat/18/05/06/p8ap02399-jumlahpasien-penyakit-ginjal-kronis-terusmeningkat diakses tanggal 19 November 2019.

Dai, S., Dai, Y., Peng, J., Xie, X., \& Ning, J. (2019). Simplified colonic dialysis with hemodialysis solutions delays the progression of chronic kidney disease. QJM: An International Journal of Medicine, 112(3), 189 196. https://doi.org/10.1093/ qjmed/hcy 260

Harismi, A., Lestari, K. (2020). Ini Prinsip Kerja Mesin Cuci Darah dan Fungsinya. Diakses 28 Desember 2020, Online: https://www.sehatq.com/artikel/mesi n-cuci-darah-beserta-fungsi-dan cara-kerjanya

Indrasari, D. N. (2015). Perbedaan Kadar Ureum dan Kreatinin pada Pasien Gagal Ginjal Kronik Berdasarkan Lama Menjalani Terapi Hemodialisa di RS PKU Muhammadiyah Yogyakarta. Naskah Publikasi
Program Studi Ilmu Keperawatan Sekolah Tinggi Ilmu Kesehatan 'Aisyiyah Yogyakarta. Online: http://digilib.unisayogya.ac.id/196/1/ NASKAH\%20PUBLIKASI\%20FIX. pdf

Kemenkes RI. (2018). Peran Pemerintah dalam Pencegahan dan Pengendalaian Gangguan Ginjal pada Anak. Direktorat P2PTM Kemenkes RI. Online: http://p2ptm.kemkes.go.id/uploads/V HcrbkVobjRzUDN3UCs4eUJ0dVBn dz09/2018/11/Paparan_dr_Cut_Putri_ Arianie_MH_Kes_Direktur_P2PTM_ Media_Briefing_Kenali_Gangguan_ Ginjal_Pada_Anak_13_November_20 18.pdf

Kementerian Kesehatan RI. (2018). Hasil Utama Riskesdas Tahun 2018. Badan Penelitian dan Pengembangan Kesehatan Kemenkes RI. Online: http://www.kesmas.kemkes.go.id/asset s/upload/dir_519d41d8cd98f00/files/H asil-riskesdas-2018_1274.pdf

Lydia, A. (2019). Jumlah Penderita Penyakit Ginjal Kronis Meningkat, Upaya Pencegahan Diperlukan. Rakyat Merdeka. Online: https://rmco.id/bacaberita/megapolitan/19434/jumlahpenderita-penyakit-ginjal-kronismeningkat-upaya-pencegahandiperlukan

Ministry of Health Republic of Indonesia [MOHRI]. (2017). No Title. InfoDATIN. Retrieved from www.depkes.go.id/download.php?.../ infodatin/infodatin ginjal

Nursiyah. (2020). Pengaruh Hemodialisa 
Terhadap Kadar Ureum dan Kreatinin Darah Pada Pasien Gagal Ginjal Kronik yang Menjalani Hemodialisis di RSUD dr. Chasbullah Abdul Madjid Kota Bekasi Tahun 2019. Online: http://ecampus.imds.ac.id/xmlui/han dle/123456789/149

Rahman, M. T. S. A., Kaunang, T. M. D., \& Elim, C. (2016). Hubungan Antara Lama Menjalani Hemodialisis Dengan Kualitas Hidup Pasien Yang Menjalani Hemodialisis di Unit Hemodialisis. Jurnal E-Clinic (ECl, 4(1), 36-40.

Ridlo, I. A. (2019. Inilah Daftar Penyakit Penyebab Kematian Tertinggi di Indonesia. Berita Fakultas Kesehatan Masyarakat UNAIR. Online: https://fkm.unair.ac.id/inilah-daftarpenyakit-penyebab-kematiantertinggi-di-indonesia/

Roma, Y. (2017). Faktor risiko penyakit gagal ginjal kronik berdasarkan status DM di RSUP DR. M. Djamil Padang tahun 2016. Skripsi Universitas Andalas. Online: http://scholar.unand.ac.id/28522/2/BA B\%20I\% 20\%28PENDAHULUAN\% 29.pdf

Rendy, C. M. (2012). Asuhan Keperawatan Medikal Bedah Penyakit Dalam. Yogyakarta: Nuha Medika.

Sitoresmi, H., Irwan, A. M., \& Sjattar, E. L. (2020). Intervensi Keperawatan Pada Penderita Gagal Ginjal Kronik Yang Menjalani Hemodialisis: Systematic Review. Jurnal Ilmiah Keperawatan (Scientific Journal of Nursing), 6(1), 108-118. https://doi.org/10.33023/jikep.v6i1.4 51

Tandi, M., Mongan, A., Manoppo, F. (2014). Hubungan antara Derajat Penyakit Ginjal Kronik dengan Nilai Agregasi Trombosit di RSUP Prof. Dr. R. D. Kandou Manado. Jurnal eBiomedik (eBM), Volume 2, Nomor 2, Juli 2014 Online: https://media.neliti.com/media/public ations/68338-ID-hubungan-antaraderajat-penyakit-ginjal.pdf

Theresia, I. (2011). Peranan Hemodialisis Dalam Upaya Menurunkan Kadar Ureum dan Kreatinin Pada Pasien Gagal Ginjal Kronik di Ruang Hemodialisis RSUP Dr. Wahidin Sudirohusodo Makassar. Skripsi tidak diterbitkan. Makassar: Program Studi S1 Keperawatan - SNHM

Usrds. (n.d.). 2017 USRDS Annual Data Report: Executive Summary. Retrieved from https://www.usrds.org/2017/downloa d/2017_Volume_1_CKD_in_the_US .pdf

Widiana, I. G. R. (2013). Preskripsi dan Adekuasi Hemodialisis. Jurnal Ilmiah Kedokteran Universitas Udayana. Online: https://ojs.unud.ac.id/index.php/medi cina/article/download/6835/5164 